\title{
Re-establishment of Entodinium caudatum, Cultured in vitro, in the Rumen of a Defaunated Sheep
}

\author{
By G. S. COLEMAN AND R. W. WHITE \\ Biochemistry Department, Agricultural Research Council \\ Institute of Animal Physiology, Babraham, Cambridge
}

(Accepted for publication I6 April I970)

Rumen Entodiniomorphid protozoa have been grown in vitro (e.g. Hungate, 1942, I943; Coleman, 1958, I969), but certain morphological structures were sometimes lost after a period of growth under these conditions. It was therefore of interest to determine if such protozoa were still capable of growth in the rumen.

The protozoon chosen was Entodinium caudatum that had lost the caudal spine during in vitro culture for $9 \frac{3}{4}$ years (Coleman, I960). A Clun Forest ewe with a rumen cannula was defaunated with dioctyl sodium sulphosuccinate (Abou Akkada et al. I968). It was fed daily on $800 \mathrm{~g}$. hay and $200 \mathrm{~g}$. crushed oats, kept in a building that contained no other ruminants and tended by persons having no other contact with ruminants. Under these conditions the animal was maintained without rumen ciliate protozoa for over 2 months until deliberately reinoculated. However, the microscopic appearance of the rumen contents changed on defaunation and remained abnormal even after reinoculation in that they contained large numbers of Oscillospira guillermondii and other 'large bacteria'. The inoculum was $5 \mathrm{ml}$. of a washed suspension of E. caudatum containing $10^{7}$ protozoa. A week after inoculation protozoa were visible in a drop of rumen contents and after 4 weeks $\mathrm{I} \cdot 3 \times 10^{6}$ protozoa $/ \mathrm{ml}$. were present compared with only $3 \times 10^{5} / \mathrm{ml}$. in the culture in vitro. The protozoa appeared to grow directly after inoculation. E. caudatum was the only ciliate protozoon in the sheep for 3 months until the animal was returned to housing where it had contact with other sheep and where it became infected with small numbers of E. simplex. Seven months after reinoculation (at the time of writing) these were still the only ciliate protozoa present and there was no evidence of the reappearance of the caudal spine in $E$. caudatum. This observation was not unexpected, as Eadie (1967) showed that when $E$. caudatum was grown as the major ciliate species in an isolated sheep it gradually lost its caudal spine.

White (I969) found that each Entodinium caudatum organism grown in vitro (Coleman, 1960) contained $21 \cdot 8 \pm 8 \cdot 2$ bacteria. These were principally Klebsiella aerogenes and Proteus mirabilis, which grew equally well aerobically or anaerobically. It was therefore of interest to investigate the change, if any, in the number and nature of the intracellular bacteria on transfer to the rumen. Rumen samples were taken from the sheep at weekly intervals for Io weeks, beginning 6 weeks after reinoculation and continuing until the appearance of Entodinium simplex. Fifty ml. rumen contents strained through muslin were diluted with $50 \mathrm{ml}$. of salts medium (Coleman, 1958) containing $0.25 \%(\mathrm{w} / \mathrm{v})$ L-cysteine hydrochloride. This diluted material was stood for I min. and then the top $90 \mathrm{ml}$. was centrifuged for I min. from starting the centrifuge 
(maximum R.C.F. 500g). The pelleted protozoa were washed 4 to 5 times on the centrifuge in the salts-cysteine medium and finally resuspended at a population density of approximately $5 \times 10^{5} / \mathrm{ml}$. Thereafter the procedures for ultrasonic breakage of the protozoa and bacteriological examination of the material were as described by White (1969). The average bacterial count per protozoon in a suspension of the washed protozoa was $\mathrm{I} \cdot 66 \pm 0.7 \mathrm{r}$ before breakage and $22 \cdot 29 \pm \mathrm{I} 2.55$ after breakage. As each protozoon disintegrated in the agar medium after sonic treatment, liberating its intracellular bacteria, the minimal count obtainable with intact protozoa was $\mathrm{I}$. The washed protozoa thus contained very few extracellular bacteria. Although the number of intracellular bacteria had not changed markedly the nature of the flora in the protozoa had altered as no bacteria grew aerobically on plates of Oxoid nutrient agar containing $0.5 \%$ (w/v) glucose (Oxoid Division of Oxo Limited, Thomas House, Queen Street Place, London, E.C. 4). Examination of liquid cultures in the medium of Bryant \& Robinson (196I) grown from colonies taken from the isolation medium showed the existence of three main morphological types of bacteria : (a) small Gramnegative cocci resembling Veillonella spp.; $(b)$ small curved or curled Gram-negative bacteria resembling Butyrivibrio spp.; and (c) Gram-positive cocci resembling Streptococcus bovis. Occasionally other morphological types were found, and for the purposes of determining the numbers of each type present these were included in group $(c)$. In 76 separate cultures obtained from disrupted protozoa, bacteria of type $(a)$ were seen 49 times, those of type (b) 25 times and those of type $(c)$ I 2 times.

These results show that when Entodinium caudatum was resettled in the rumen there was a change in the intracellular bacteria to ones morphologically similar to those found in the rumen.

We wish to thank Dr R. M. C. Dawson and Dr P. Kemp, who defaunated the sheep, and Mrs M. E. Black, Mrs B. C. Barker and Mr D. J. Lander for skilled technical assistance.

\section{REFERENCES}

Abou Akkada, A. R., Bartley, E. E., Berube, R., Fina, L. R., Meyer, R. M., Hendricks, D. \& Julrus, F. (1968). Simple method to remove completely ciliate protozoa of adult ruminants. Applied Microbiology 16, 1475-1477.

Bryant, M. P. \& Robinson, I. M. (196I). An improved non-selective culture medium for ruminal bacteria. Journal of Dairy Science 44, 1446-1456.

Coleman, G. S. (1958). Maintenance of oligotrich protozoa from the sheep rumen in vitro. Nature, London 182, $1104-1105$.

Coleman, G. S. (1960). The cultivation of sheep oligotrich protozoa in vitro. Journal of General Microbiology 22, 555-563.

Coleman, G. S. (1969). The cultivation of the rumen ciliate Entodinium simplex. Journal of General Microbiology 57, 8I-90.

EADIE, J. M. (1967). Studies on the ecology of certain rumen ciliate protozoa. Journal of General Microbiology 49, I75-194.

Hungate, R. E. (1942). The culture of Eudipodinium neglectum, with experiments on the digestion of cellulose. Biological Bulletin. Marine Biological Laboratory, Woods Hole, Mass. 83, 303-319.

Hungate, R. E. (1943). Further experiments on cellulose digestion by the protozoa in the rumen of cattle. Biological Bulletin. Marine Biological Laboratory, Woods Hole, Mass. 84, I57-163.

WhIte, R. W. (I969). Viable bacteria inside the rumen ciliate Entodinium caudatum. Journal of General Microbiology 56, 403-408. 